\title{
Apprasal of Investment Volume and Per Capita in Nigeria during Financial Reforms
}

\author{
Mfon Nathaniel Udo Akpan
}

\begin{abstract}
This study was carried out to evaluate the Impact of financial reforms on investment and per capita income in Nigeria. Specifically, the study sought to assess the performance of Nigerian Banks as influenced by changes in the economy as well as changes in other sectors of the financial system. In carrying out this research, secondary data were used while ex-post facto research design was employed. Following a forty year review of the performance of Nigeria's economy in tandem with the performance of Banks in the face of the ebbs and flows of the identified parameters. the study notes two eras of pre-reform (1970-1985) and the reformed (1995-2010) financial eras. Using both descriptive statistics and analytical methods, regression analyses were conducted and based on the results, it was discovered among other things that there was no significant difference in the growth and development of the economy vis-a-vis bank performance during the pre-reformed compared to the reformed financial era in Nigeria. To this end it was concluded that reforms so far implemented have not significantly move the economy foreword and consequently banks have not also performed as had been expected but rather the reforms have created avenues for executive fiat, corruption and embezzlement of public funds.
\end{abstract}

\section{Introduction}

The world over, many economies have undergone various types of reforms. This is to enable them cope with changing economic cycles, developments and challenges. Nigeria is no exception. Different sectors of the economy have also undergone several types of reforms. Reforms here mean to improve a system, an organisation, a law, etc by making changes to it, (Hornby, 2001). The point is that reforms are gradual, continuous and of varieties. For instance, there are economic, political, social, and/or financial reforms, to mention but a few.

Economic reforms are the pursuits of fiscal reforms and market liberalization, which focus on extensive privatization of state owned enterprises as well as liberalization of financial and foreign exchange markets, with government limited to provision of the right enabling environment for a private sector led growth and development (World bank, 1986). Theodore (2007) opined that social reform means any attempt to alter or effect change in the society, even if it means making some radical exploit to alleviate human sufferings and deprivations of all ramifications without losing sight of the ultimate desirable democratic order. Such change could be in the form of social groups, structures and types of associations/interactions among member of the society, while according to Dele (2007) financial reforms focus mainly on restructuring financial sector institutions (regulators and operators) through institutional and policy reforms. They are always targeted toward market liberalization for the promotion of a more efficient resource allocation, expansion of savings mobilization base, promotion of investment and growth through market-based interest rates and above all, laying the basis for inflation control and economic growth and development.

The concern of this article is on Investment volume and per-capita income. This study therefore examines the impact of financial reforms on investment volume and per-capita income and Economic growth and development in the economy. Economic growth means an increase in output per unit of input, while economic development means more outputs plus changes in the technical and institutional arrangement by which the outputs are produced (Udu and Agu, 1989). while economic growth and development are measured through the use of major economic indicators such as growth rate of gross domestic product $\left(\mathrm{GDP}_{\mathrm{r}}\right)$, volume of investment in the economy and human development index and consumer price index rate respectively.

\subsection{Objectives of the Study}

The study sought to establish the relationship existing between economic growth and development and financial reforms in Nigeria. To

(i) Ascertain the relationship that exists between the aggregate public investment and bank asset base $(\mathrm{BAB})$, insurance asset base, stock market capitalisation rate and foreign exchange reserves in Nigeria. Establish whether any significant relationship exists between the per capita income and bank asset base $(\mathrm{BAB})$, insurance asset base, stock market capitalisation rate and foreign exchange reserves in Nigeria. 


\subsection{Research Questions}

i. Is there any significant relationship existing between the aggregate public volume of investment and bank asset base, insurance asset base, stock market capitalisation and foreign exchange reserves in Nigeria?

ii. Has per capita income any relationship with bank asset base, insurance asset base, stock market capitalisation and foreign exchange reserves in Nigeria?

\subsection{Research Hypotheses}

These hypotheses are stated in their null forms below:

i. Ho: Aggregate public investment has no significant relationship with bank asset base, insurance asset base, stock market capitalisation and foreign exchange reserves in Nigeria?

ii. Ho: Per capita income has no significant relationship with bank asset base, insurance asset base, stock market capitalisation and foreign exchange reserves in Nigeria?

\subsubsection{Theoretical Review}

\section{Literature Review}

Judging from the pedigrees of supporting theories, discussion on financial reforms and economic growth and development is not new. Financial reform has long been recognised to play an important role in the economic growth and development of a nation. This recognition dates back to Goldsmith (1955), Cameron (1967), McKinnon (1973), and Shaw (1973). They demonstrated that financial sector could be a catalyst of economic growth and development if it is developed and healthy. Since then efforts have been made in quite a number of literatures to fathom out the ties between these phenomena.

This study therefore, pitches its tent on the framework of theoretical reasoning and evidences that suggest a positive, first-order relationship between financial reform and economic growth and development. A growing body of work that are conducted on this theory have pushed even most sceptics toward the belief that the reform of the financial sector (market and institutions) is a critical and inextricable part of the growth and development process, and away from the view that the financial system is an inconsequential side show, responding passively to economic growth and development

\subsection{Research Design}

\section{Research Methodology}

This specifically $\mathrm{x}$-rays the designs, procedures, and techniques that clearly show or tell us how this study is conducted. Items here include: the research design, research area, source and types of data, methods of data collection, and problems of data collection, model specification, and techniques of data treatment.

In this study, the ex post facto research design was employed. Ex post factor (i.e. after the fact) research is a research that is undertaken after the event has taken place and the data are already in existence (Ndiyo, 2005). The choice of this design is informed by the hybrid nature of this research. It is hybrid in the sense that it has some descriptive and experimental features, and the ex post factor design is midway between descriptive and experimental research. It is descriptive in that the researcher has no direct control over experimental conditions, while it is experimental because an attempt is made to infer causal relationships between groups, which differ in important ways. It is to explore the causal relationship existing between two or more variables as is the case in this study.

\subsection{Research Area}

This study is conducted in the area of financial reform and economic growth and development. Its thrust is specifically on examining the impact that financial reforms could mete out on economic growth and development of a nation. In this study, I use Nigeria as a case. Thus, this research is carried out in Nigeria to examine the impact of financial reforms on the growth and development of her economy.

\subsection{Sources of Data}

The data used were secondary data. Secondary data refers to those pieces of information, facts, figures, and detailed opinions generated and documented by other people to satisfy entirely different research works but were found to be relevant to this study. Specific types of data required are as listed under their category below:

\section{Measures of Financial Reforms:}

(i) Bank asset base (BAB) from the banking sector, 
(ii) Aggregate insurance asset base (IAB),

(iii) Stock market capitalization rate (SMCR), and

(iv) Foreign exchange reserves (FER).

2. Economic Growth (EG) Indicators:

(i) Growth rate of gross domestic product $\left(\mathrm{GDP}_{\mathrm{r}}\right)$, and

(iii) Aggregate public investment designated as volume of investment (VI).

3. Economic Development (ED) Indicators:

(i) Per capita income (PCI), and

(iii) Consumer price index (CPI).

However, these data were drawn from the following sources: The Central Bank of Nigeria (CBN) and International Monetary Fund (IMF) statistical Bulletin, economic reviews, monetary survey data, Annual Reports and Statement of Accounts; Annual Abstract of Statistics from the National Bureau of statistics (NBL), Bureau of Labour Statistics (BLS), annual reports and statements of account; Accounts of institutions and information from Federal Ministry of Finance and Economic Development; Textbooks and other publications; Website and Internet-based sources.

\subsection{Model Development/Specification}

Economic "growth" and "development" are often used synonymously in economic discussion, but they can be distinguished from each other. Economic growth means more output, which implies more input and more efficiency - that is an increase in output per unit of input (Udu and Agu, 1989:232). It is the rate at which the economy grows per annum and is measured in this study by the growth rate of gross domestic product $\left(\mathrm{GDP}_{\mathrm{r}}\right)$, and volume of investment (VI) etc. In this study, it is postulated that economic growth, proxy by GDPr and VI is influence by financial reforms proxy by bank asset base (BAB) Insurance Asset Base (IAB), stock market capitalization rate (MCR) and foreign exchange reserves (FER). Our first set of models and their implicit regression equations are therefore given thus:

(1) $\quad E G \quad=f(B A B, I A B, M C R, F E R)$ :

(i) $\quad G D P_{r}=f(B A B, I A B, M C R, F E R)$

$G D P_{r}=a_{o}+b_{1} X_{1}+b_{2} X_{2}+b_{3} X_{3}+b_{4} X_{4}+e$

$G D P_{r}=a_{o}+b_{1} B A B+b_{2} I A B+b_{3} M C R+b_{4} F E R+e \ldots E q t n 1$

(ii)

$$
\begin{aligned}
& V I=f(B A B, I A B, M A R, F E R): \\
& V I=a_{o}+b_{1} X_{1}+b_{2} X_{2}+b_{3} X_{3}+b_{4} X_{4}+e \\
& V I=a_{o}+b_{1} B A B+b_{2} I A B+b_{3} M C R+b_{4} F E R+e \ldots . . . E q t n 2
\end{aligned}
$$

where $E G=$ Economic growth measured by $G D P_{r}$ and VI, each being a function of $(f) X_{1}=B A B, X_{2}=I A B$, $X_{3}=M C R, X_{4}=F E R$ as defined above, and $e=$ error term, $a_{o}=$ estimate of the true intercept of the dependent variables or regression constant; $b_{1 . . n}=$ estimate of the true parameters of the independents variables or regression coefficients

Economic development (ED) on the other hand, implies that there are both more output and changes in the technical and institutional arrangement by which the output is produced. It implies changes in the structure of outputs and in allocation of inputs by production sector. Udu and Agu (1989:232) defined economic development as the process whereby the level of national production (i.e., national income) or per capita income, increase over a period of time and is measured in this study by per capita income (PCI) and Consumer Price Index (CPI). In the same vein, ED proxy by PCI and CPI is influence by financial reforms as express in our second set of models below:

$$
\begin{aligned}
& E D=f(B A B, I A B, M C R, F E R): \\
& P C I=f(B A B, I A B, M C R, F E R) \\
& P C I=a_{o}+b_{1} X_{1}+b_{2} X_{2}+b_{3} X_{3}+b_{4} X_{4}+e \\
& P C I=a_{o}+b_{1} B A B+b_{2} I A B+b_{3} M C R+b_{4} F E R+e \ldots . . E q t n 3 \\
& C P I=f(B A B, I A B, M C R, F E R) \\
& C P I=a_{o}+b_{1} X_{1}+b_{2} X_{2}+b_{3} X_{3}+b_{4} X_{4}+e \\
& C P I=a_{o}+b_{1} B A B+b_{2} I A B+b_{3} M C R+b_{4} F E R+e . . . . E q t n 4
\end{aligned}
$$

All variables are as defined earlier on in the preceding sections.

Generally, while measures of financial reforms constitute the independent variables, measures of economic growth and development constitute the dependents variables of the study. Thus eqtns $\mathbf{1}-\mathbf{4}$ would be estimated through a simultaneous regression estimation procedure. This estimation procedure is often adjudged to yield better result and more efficient estimate of the parameters and coefficient of the regression than the single equation model especially where two or more independent variables are involved. In its implicit form the multiple regression models would be rendered as:

$$
Y=a+b_{1} B A B+b_{2} I A B+b_{3} M C R+b_{4} F E R+e .
$$




GAUSS MARKOV MODEL: Linearity in Parameters
where: $Y \quad \begin{aligned} & \text { the estimate value of the dependent variable, given specific value of } \\ & \text { independent variables; }\end{aligned}$
$\begin{array}{cl}a_{0} & =\quad \text { estimate of the true } Y \text { intercept or regression constant; } \\ b_{1 . . n} & \text { estimate of the true parameter of the independent variables or } \\ & \text { regression coefficient; } B A B, I A B, M C R, F E R \text {, are as defined earlier. }\end{array}$

\subsection{Method of Data Analysis}

In this study, the multiple regression method will be employed to analyze data. The model for this statistics is given as:

$$
Y=a+b_{1} B A B+b_{2} I A B+b_{3} M C R+b_{4} F E R+e .
$$

The use of regression in the analysis is to assist in identifying the independent variable that best explains and significantly impacts on the dependent variable of the research. For purpose of testing the hypotheses, three tests:- the t-test, the F-test statistics and ANOVA was employed. While the t-test was used to measure the statistical significant of the regression coefficients and to determine the flow or direction of the relationship existing between the two variables, the F-test was employed to measure the adequacy or appropriateness of the model and to arrive at a conclusion on the statistical significance of the coefficient of determination $\left(\mathrm{r}^{2}\right)$. All the hypotheses will be tested at $95 \%$ level of significance. The result generated base on the application of Mat lab, a computer based software programme will be compared with the tabulated $t$ and $f$ statistics respectively at $\mathrm{P}=0.05$. Consequently, the decision rule for accepting or rejecting the hypotheses is based on:

(i) Accept $H_{o}$ and reject $H_{i}$ if $f_{t} 0.05>f_{C}$

(ii) Reject $H_{o}$ and accept $H_{i}$ if $f_{t} 0.05<f_{C}$

That is, we accept the null hypotheses $\left(\mathrm{H}_{\mathrm{o}}\right)$ and reject the alternative hypotheses $\left(\mathrm{H}_{\mathrm{i}}\right)$ where the tabulated or critical $\mathrm{F}$ value is greater than our computer generated $\mathrm{F}$ value at $5 \%$ level of significance and vice versa. Similarly the significance and relevance of the parameter estimate of our test is considered at where: $\boldsymbol{t}_{\boldsymbol{C}}$ $0_{0.05}>t_{t}$ and insignificance and non-relevance at where $t_{C} 0.05<t_{t}$.

The use of F- statistic in determining whether or not to reject the hypotheses is simply because of its prime or superior position to the t-test as noted by McCullough (1974) thus: "if f-test result is true, then t-test must be true and not vice-versa". Finally, an ANOVA used to compare and analyse any observed differences in economic growth and development in periods of financial repression as well as in the periods of financial reform.

\subsection{Data Presentation}

\section{Data Presentation Analysis And Interpretation}

This present, analyze and interprets the data collected for the study. Data used in this study were collected based on the variables identified in the research objectives, research questions and hypotheses. Thus the data were presented to reflect the research objectives and the problems identified.

\subsection{Data Analysis}

The data in Appendix A underpins the analytical framework for this study. It is pivotal to and a springboard from which subsequent data and Appendices are extracted and analyzed specifically for each index of economic growth and development against those of financial reforms. The data presented in Appendix A covers the period of forty-one (41) years, (1970-2010). In it, it is shown that financial reforms are examined in terms of bank asset base (BAB), insurance asset base (IAB), foreign exchange research (FER) and stock market capitalization (SMC). Economic growth is examined in terms of growth rate of gross domestic product (GDPr) and aggregate public investment, i.e. investment volume (IV), while economic development is examined in terms of per capita income (PCI) and consumer price index (CPI).

\section{APPENDIX A}

The Relationship between Growth Rates of Gross Domestic Product (GDPr), Investment Volume (IV), Growth Rate of Per Capita Income (PCIr), Consumer Price Index (CPI), Bank Asset Base (BAB), Insurance Asset Base (IAB), Foreign Exchange Reserves (FER), and Stock Market Capitalization (SMC),( 1970 - 2010)

\begin{tabular}{|l|l|l|l|l|l|l|l|l|}
\hline Years & GDPr $(\%)$ & $\begin{array}{l}\text { IV } \\
(\%)\end{array}$ & PCIr (\%) & $\begin{array}{l}\text { CPI } \\
(\%)\end{array}$ & $\begin{array}{l}\text { BAB } \\
(\%)\end{array}$ & $\begin{array}{l}\text { IAB } \\
(\%)\end{array}$ & $\begin{array}{l}\text { FER } \\
(\%)\end{array}$ \\
\hline 1970 & 46.80 & 18.80 & 21.98 & 0.23 & 51.19 & 64.40 & 8.10 & 1.20 \\
\hline 1971 & 26.33 & 16.60 & 11.47 & 0.23 & 10.80 & 64.20 & 8.10 & 11.80 \\
\hline 1972 & 8.45 & 24.50 & 0.85 & 0.24 & 12.70 & 54.60 & 9.20 & -24.86 \\
\hline 1973 & 59.09 & 31.50 & 2.77 & 0.28 & 23.03 & 53.60 & 24.80 & 23.97 \\
\hline
\end{tabular}


Apprasal Of Investment Volume And Per Capita In Nigeria During Financial Reforms

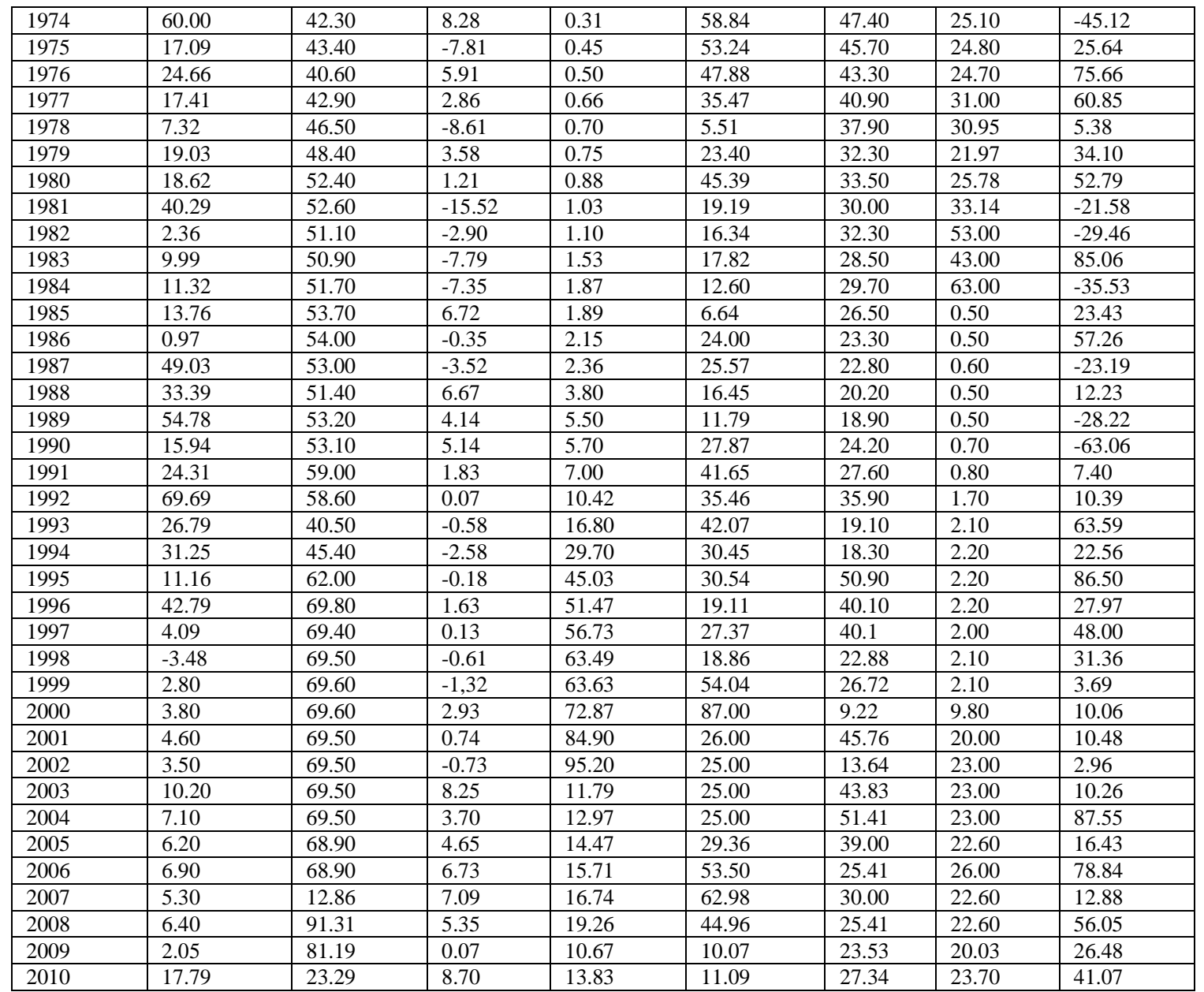

Sources: CBN statistical Bulletin (Various yrs), CBN Annual Report and Statement of Accounts (Various yrs) Nigerian Quarterly Economic Review.

From the data above in Appendix A, between 1970 and 1990, Nigeria's bank asset base maintained high volatility rate as it rose and fell frequently throughout the years. From 1991-2008 not much volatility. But decline significantly between 2008(34.89\%) and $2010(1.02 \%)$. This trend is best described in the Fig. below. 

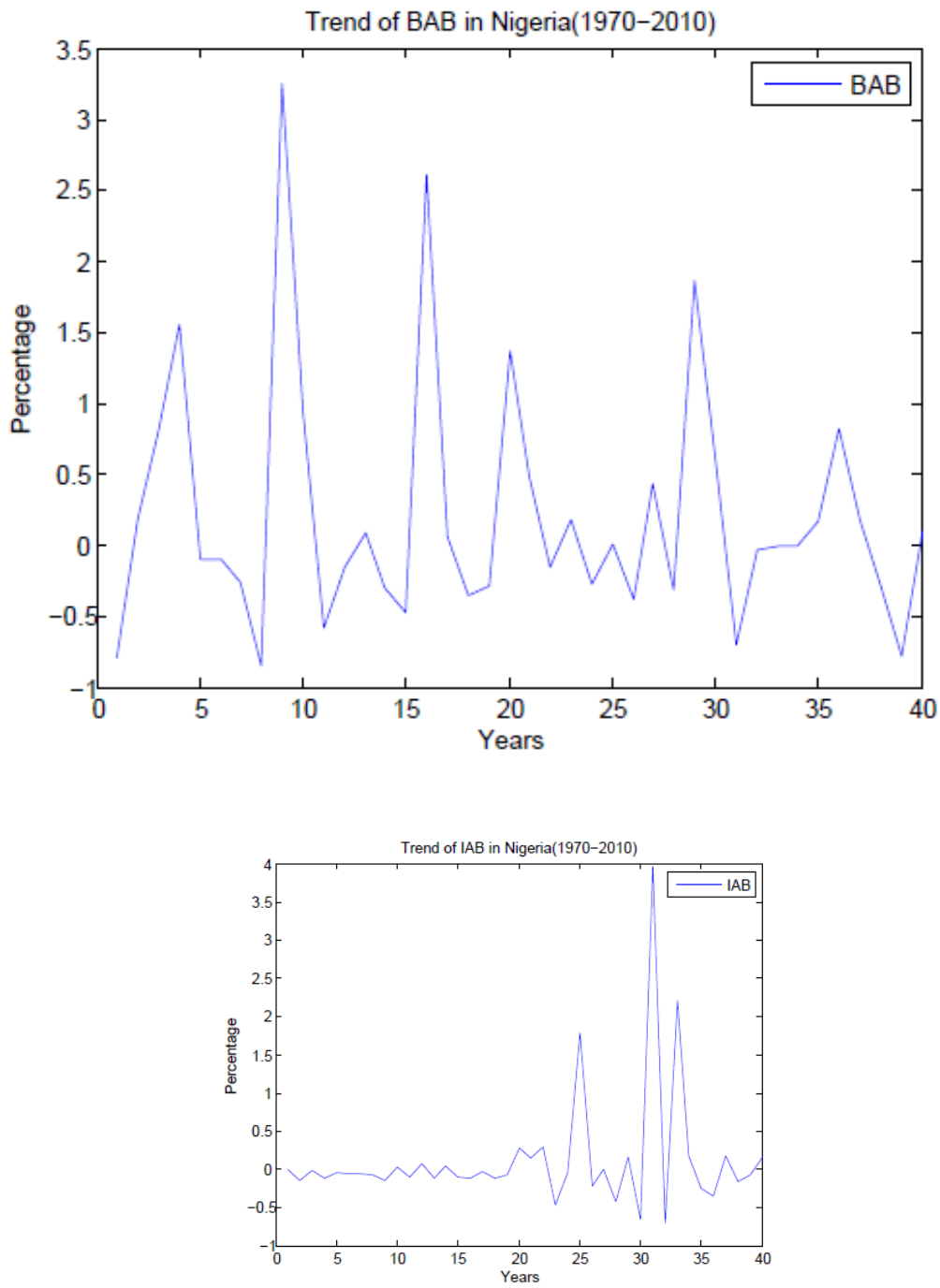

The data for insurance asset base were logged to give the picture of the trend of IAB in Nigeria as presented in Fig. above.

Insurance asset base during the period decline on average by $3.12 \%$ consistently. In 1982 , IAB rose by a $2.30 \%$, declined in 1983 by $3.8 \%$ and increased again by $1.2 \%$ in 1984 . From 1985 to 1989 , an average of $2.16 \%$ decline was recorded, while an average of 5.66\% increase was recorded between 1990 and 1992. In 1993 and $1994,16.8 \%$ and $0.8 \%$ decrease were recorded respectively 1995 had an increase of 32.6\%. Between 1996 and 2007 there was stability following a 10.8\% decrease in 1996. From 2008 a declined of $(4.59 \%), 2009(1.88 \%)$ and an increased of $(1.88 \%)$ for 2010. 


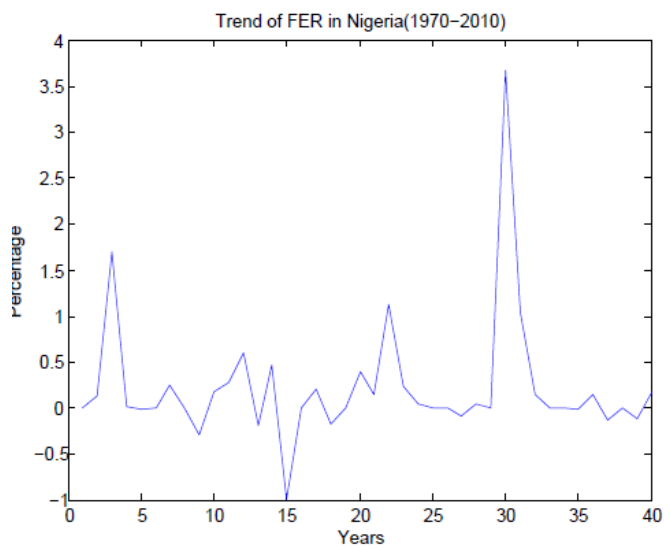

The trend of foreign exchange reserve is above. Foreign exchange reserve rose from $0.01 \%$ in $1972-00.15 \%$ in 1973 and rose again by $0.06 \%$ in 1977 to about $2.78 \%$ in 1978 and by $0.53 \%$ from 1980 to 1981 . From 1985, a large decline of about (62.5\%) was recorded counting from 1991. Between 1988 and 1990, there was relative stability with an average of about $0.13 \%$ volatility rate in the positive direction. It rose by $10.2 \%$ in 2000 and by $3 \%$ in 2001 and remain stable through 2004 when it declined by only $0.40 \%$ in 2005 . In 2006, FER increased by $3.4 \%$ and to $0.40 \%$ decrease in 2007 and stabilized through to 2008 to 2010 .

The picture of the trend of Nigeria's SMCr under review is presented below.

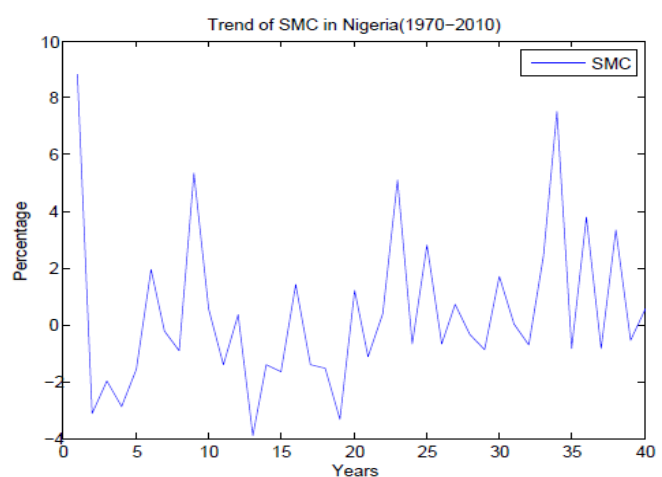

Stock market capitalization maintained, on average, a $0.07 \%$ increase between 1970 and 1975 when it rose by $0.48 \%$ in 1976 and maintained an average of $0.65 \%$ increase from 1976 - 1980. In 1981 and $1982 \mathrm{SMCr}$ declined by $31.21 \%$ and $7.88 \%$ respectively. It rose by $55.6 \%$ in 1983 and declined again by $49.53 \%$ in 1984 . Other years that SMC grow and their percentages are: 1985(12.1\%), $1986(33.83 \%), 1988(10.96 \%), 1992-$ 1994 (2.47\% on average), 1995(63.94\%), 1996 declined of (58.53\%), 1997 rose by (20.03\%), declined of $(7.52 \%) 2002,2003$ rose by $(7.3 \%)$, rose by $(77.29 \%)$ in 2004 . Declined by $(71.12 \%)$ in 2005 . and a significant positive volatility between $2007-2010$.

\subsection{Test of Research Hypotheses}

As stated earlier, financial reforms are measured in this study by bank capital base (BAB), insurance asset base (IAB), foreign exchange reserves (FER) and stock market capitalization (SMC). Economic growth is measured by growth rate of gross domestic product (GDPr) and investment volume (IV), while economic development is measured by per capita income (PCI) and consumer price index (CPI).

\subsubsection{Hypothesis Two}

The second hypothesis addressed the second objective of this study which was to find out the relationship between volume of investment and bank asset base, insurance asset base, foreign exchange reserves and stock market capitalization. Based on this, our second hypothesis was then made thus:

Volume of investment has no significant relationship with bank asset base, insurance asset base, stock market capitalization and foreign exchange reserves in Nigeria? 
Data relating to the variables in hypothesis two above were plotted and the interactive graph explaining the relationship at a glance plotted and presented below.

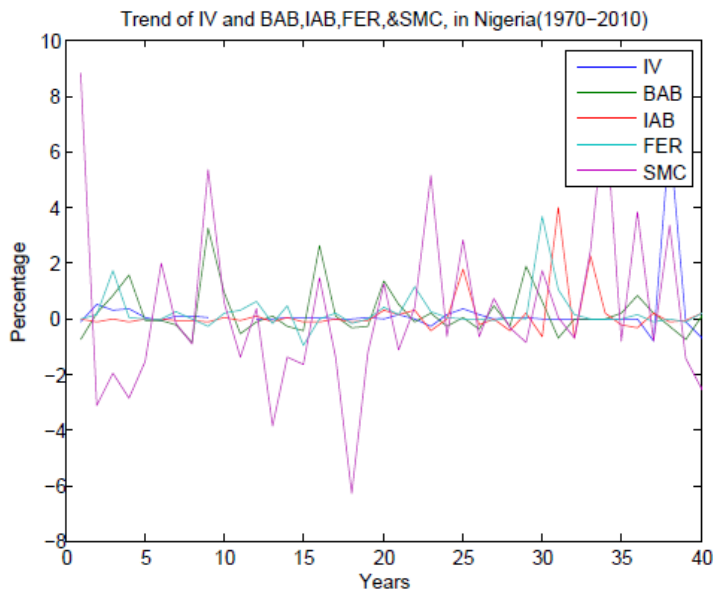

The log values of the parameters is given as:

$\mathrm{VI}=\mathrm{a}_{\mathrm{o}}+\mathrm{b}_{1} \mathrm{CBAB}+\mathrm{b}_{2} \mathrm{IAB}+\mathrm{b}_{3} \mathrm{MCR}+\mathrm{b}_{4} \mathrm{FER}+\mathrm{e} \ldots \ldots .$. Eqtn 2

The regression result of the above equation as extracted from Table 4.2 is presented below:
IV =
70.7628
$(-0.147)$
$(-2.702)$
$(-0.068)$
$(0.746)$
$\mathrm{R}^{\mathrm{t}}{ }_{\mathrm{stat}}=$
$=11.69 \%$
$\mathrm{F}(4,36)=1.8271$

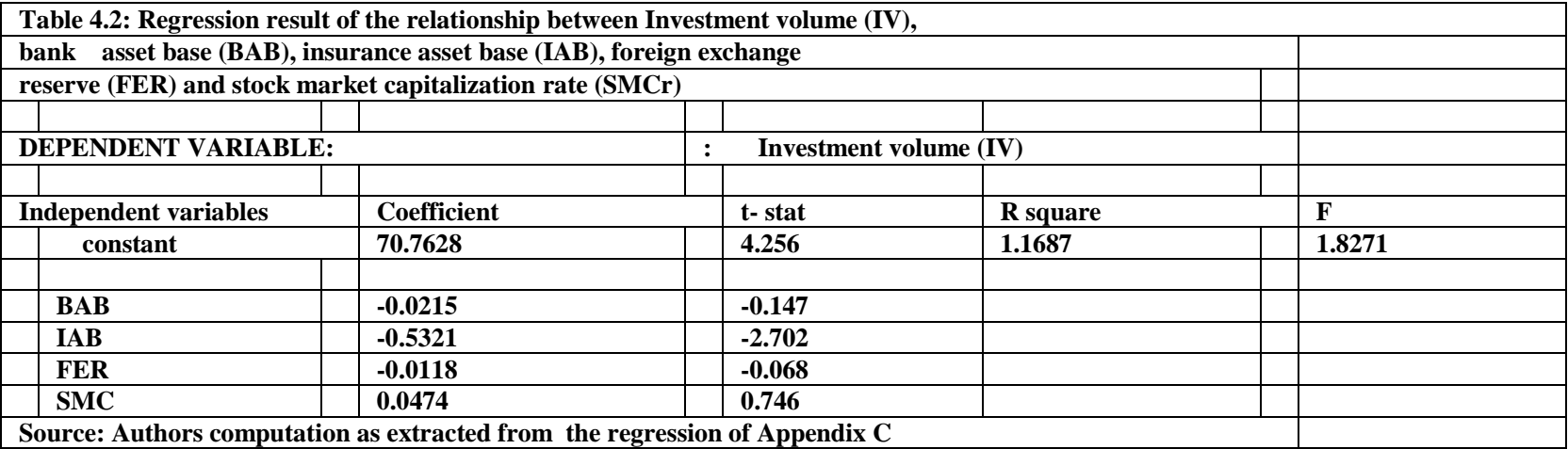

(a) Predictors: (Constant), BAB, IAB, FER, and SMC.

(b) Dependent Variable: IV

$\mathrm{R}^{2}=11.69 \%, \quad \mathrm{~F}(4,36)=1.8271$,

Level of Significant $=95 \%$ level

As shown in the regression result above, average investment volume was $\mathbf{7 0 . 7 6 2 8}$ during the period reviewed. With regards to the explanatory variables, a one naira increase in BAB reduced investment volume by $-N$ 0.0215 while insurance asset base reduced investment volume by - N0.5321 and stock market capitalization increase investment volume by $\mathbf{N 0 . 0 4 7 4}$. Also, foreign exchange reserves reduced investment volume by N0.0118.All other things being equal.

The significance of the variations in the dependent variables as explained by the independent variable was determined by comparing our calculated $f\left(f_{C}\right)$ value of $\mathbf{1 . 8 2 7 1}$, at $95 \%$ level of significance and thirty nine degrees of freedom with the critical value of $f\left(f_{t}\right)$ of 2.65 . With $f_{C}$ value less than $f_{t}$ value, the null hypothesis which states that Volume of investment has no significant relationship with bank asset base, insurance asset base, stock market capitalization and foreign exchange reserves in Nigeria was accepted. In other words, BAB, IAB, FER, SMCr had no significant impact on average investment volume.

The statistical significance of the individual independent variables in the model was established by comparing their respective calculated $\mathrm{t}\left(\mathrm{t}_{\mathrm{C}}\right)$ values which were $\mathbf{- 0 . 1 4 7}$ for bank asset base (BAB); $\mathbf{- 2 . 7 0 2}$ for insurance asset base (IAB), $\mathbf{- 0 . 0 6 8}$ for foreign exchange reserves (FER) and $\mathbf{0 . 7 4 6}$ for stock market capitalization with the critical $t\left(t_{t}\right)$ value of 1.70 . It was seen that all the variables (BAB, IAB, FER, and SMC) had their $t_{C}$ values less than $t_{t}$ value. And they were said to be statistically insignificant in the model. This means insurance asset base impacted more or had the greatest negative impact on investment in Nigeria followed by 
bank asset base lastly foreign exchange reserves FER while SMC had a little positive of $\mathbf{0 . 7 4 6}$ impart during the period reviewed.

From the regression result, it was evident that the regression model had no good fit. Thus the econometric property of the regression equation is not remarkable, and was not said to reflect a true prediction of financial reforms contribution to economic growth of Nigeria. Its predictive power $\mathrm{R}^{2}$ of $11.69 \%$ shows that financial reform measures mentioned above do not adequately explain and contribute significantly to the variations in the investment volume in Nigeria for the period reviewed. Put it differently, Nigeria's investment volume is not affected positively and significantly by financial reforms in the country. Other variables that also influence investment volume in Nigeria but not included in this study may have accounted for the remaining $88.33 \%$ of the variations in IV.

\subsubsection{Hypothesis}

The hypothesis sought to establish the relationship between per capita income and bank asset base, insurance asset base, foreign exchange reserves and stock market capitalization. In the research hypothesis, it was stated based on this objective thus:

Per capita income has no significant relationship with bank asset base, insurance

asset base, stock market capitalization and foreign exchange reserves in Nigeria?

Data that reflect the variables in the above hypothesis were presented. The accompanied Figure below presents an interactive picture of the relationship between the parameters.

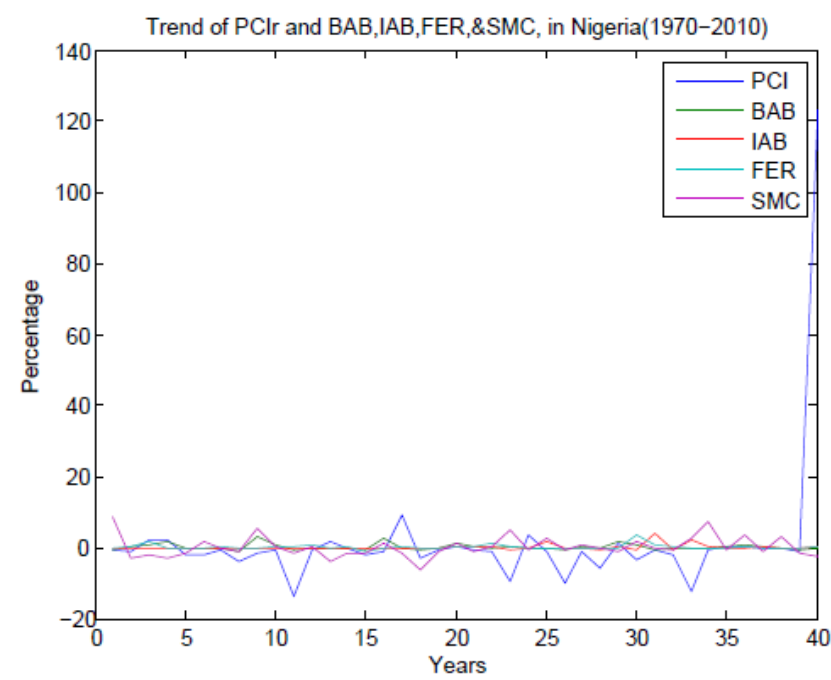

Per capita income seems not to go above the negative horizon amidst the reforms parameters.

The log values of the parameters is given as:

PCIr $=a_{o}+b_{1} B A B+b_{2}$ IAB $+b_{3}$ MCR $+b_{4}$ FER + e e......Eqtn 3

In Table 4.3 below, the regression result of the above equation was presented.

An extract of the result is as shown below:

$$
\begin{aligned}
& \mathrm{PCI}=-4.7058+0.0821_{\mathrm{BAB}}+0.1794_{\mathrm{IAB}}-0.1343_{\mathrm{FER}}+0.0074_{\mathrm{SMC}}+\mathrm{e} \\
& \mathrm{t}_{\text {-stat }}=\left(\begin{array}{lllll}
(-0.814) & (1.655) & (2.604) & (-2.625) & (0.331)
\end{array}\right. \\
& \mathrm{R}^{2} \quad=28.01 \%, \quad \mathrm{~F}(4,36)=3.5013
\end{aligned}
$$

\begin{tabular}{|c|c|c|c|c|}
\hline \multicolumn{5}{|c|}{ bank asset base (BAB), insurance asset base (IAB), foreign exchange reserve } \\
\hline \multicolumn{5}{|c|}{ (FER) and stock market capitalization rate (SMCr) } \\
\hline \multicolumn{2}{|c|}{ DEPENDENT VARIABLE: } & \multicolumn{2}{|c|}{ Per Capita Income (PCIr) } & \\
\hline Independent variables & Coefficient & t- stat & R square & $\mathbf{F}$ \\
\hline constant & -4.7058 & -0.814 & 0.2801 & 3.5013 \\
\hline & & & & \\
\hline BAB & 0.0821 & 1.655 & & \\
\hline IAB & 0.1794 & 2.604 & & \\
\hline FER & -0.1343 & -2.265 & & \\
\hline
\end{tabular}




\begin{tabular}{|l|l|l|l|l|l|l|}
\hline SMC & 0.0074 & 0.331 & & \\
\hline \multicolumn{2}{|l|}{ Source: Authors computation as extracted from the regression of Appendix D } & \\
\hline
\end{tabular}

(a) Predictors: (Constant), BAB, IAB, FER, and SMC.

(b) Dependent Variable: PCI

$\mathrm{R}^{2}=28.01 \%$, $\quad \mathrm{F}(4,36)=3.5013$

Level of significant $=95 \%$ level.

The above regression result shows that within the period under review, average per capita income was 4.7058. Considering the independent variables, a one naira increase in bank asset base would increase/improved per capita income by 0.0821 . A one naira increase in insurance asset base increases per capita income by only $¥ 0.1794$, a one naira increase in foreign exchange reserves decreased per capita income by - $\# 0.1343$, while a naira increase in stock market capitalization increased per capita income by $\$ 0.074$. all other things being equal.

The next activity was to test for the significance of the variations in the dependent variables as explained by the independent variables. The statistics used for this was the f-test statistics. At $95 \%$ level of significance and thirty nine degrees of freedom, our computed $\mathrm{f}\left(\mathrm{f}_{\mathrm{C}}\right)$ value was 3.501 yielding negative per capita income, compared to the critical $f\left(f_{t}\right)$ value of 2.65 . Since $f_{C}$ is greater than $f_{t}$ inversely, the null hypothesis which states that per capita income has no significant relationship with bank asset base, insurance asset base, foreign exchange reserves and stock market capitalization was accepted against its alternative hypothesis. This low per capita income is in support of

For the statistical significance of individual independent variable, the t-test statistics was employed in which case, the independent variables with their computed $t$-values $\left(t_{C}\right)$ of $1.655(B A B), 2.604(\mathrm{IAB}),-2.265$ (FER) and $0.331(\mathrm{SMCr})$ were all compared with the critical or table $t\left(\mathrm{t}_{t}\right)$ value of 1.70 . Among the calculated values of $t\left(t_{C}\right)$, one of the independent variable were statistically significant in the model that is the IAB. While $\mathrm{BAB}$ and SMC showed a positive relationship, FER showed an inverse relationship with PCI during the period reviewed. In other words, foreign exchange reserves exerted an insignificant negative effect on per capita income while bank asset base and stock market reserves exerted an insignificant positive effect on PCI during the period reviewed. This means increase in FER led to reduction in PCI while increase in IAB, BAB and SMC would lead to increase in PCI. As can be seen from the regression diagram the PCI was virtually below the zero level.

The econometric property of the estimated equation showed a poor predictive power given its $\mathrm{R}^{2}$ value of $28.01 \%$, meaning that financial reform measures mentioned above do not adequately explain and do not contribute significantly to the variations in the growth of Nigeria's per capita income for the period considered. The equation therefore shows a marginal prediction of financial system's contribution to economic development of Nigeria. The remaining $71.99 \%$ variations in the dependent variable are explained by other variables not included in this study. Examples are crude oil revenue, population growth among others.

\section{Conclusion}

From the analysis done in here, lots of interesting discoveries have been made. First and foremost, for forty years, Nigeria had been enjoying a relatively stable and a steady- state growth in the economy with the financial system playing a very marginal role in the growth process of the country. For the period of forty years, the study shows that the financial sector made no significant contribution to the growth of the economy (GDPr) given that their respective $t_{C}$ values of 0.167 (BAB), 1.513 (IAB), - 1.744 (FER) and -1.575 (SMCr) were all less than the $t_{t}$ value of 1.70. It was opine that there could have been some problems. It is either the gains derived from the financial sector were not channelled or used properly for development practices such as investment or the policy makers or corporate captains had pocketed and exported the gains to "safe heavens" somewhere in the western blocks for selfish and personal interest as was the opinion of the Emanugaa (2008). This must have been one of the impetuses for advocating for reforms in the sector.

For that period, economic growth (GDPr) has not been significantly impacted and no significant contribution was made thereto by BAB, IAB, FER and SMCr given the overall $\mathrm{R}^{2}$ value of $16.52 \%$. However, an inverse relationship existed between GDPr, SMC and FER. Mismanagement of our reserves as well as misappropriation of the fund and other unfavorable reserve policies of the international monetary authority (ies) could account for this inverse relationship.

\section{References}

[1]. Adebiyi, M. A. (2002). Is Financial Sector Liberalization the Cause of Banking Fragility in Nigeria? African Review of Money, Finance and Banking, 2 (3): 12 - 25.

[2]. Akpan, I. (1999). Fundamentals of Finance. Uyo: Modern Business Press Ltd.

[3]. Akpan, I. (2004). Fundamentals of Finance. $2^{\text {nd }}$ ed., Uyo: Nelgrfik Nig. Ltd. 
[4]. Arestis, P. and Demetriades, T. (1997). Financial Development and Economic Growth: Assessing the Evidence. Economics Journal, 107:783 - 99.

[5]. Atindehou, R. B., Gueyie J. P. and Amenounve, E. K. (2005). Financial Intermediation and Economic Growth: Evidence from Western Africa. Applied Financial Economics, 15: 777 - 790.

[6]. Bandiera, O., Caprico, G., Honshan, P. S. and Schiabtarille, F. (1999). Does Financial Reforms Raise or Reduce Savings? Working Paper No. 2062, World Bank.

[7]. Bio-Tchane, S. (2006). Making Reforms Work for Nigeria; African Department IMF. This Day. (Nigeria) May 18, 2006.

[8]. Central Bank of Nigeria, Lagos (2001). The Impact of Structural Adjustment Programme on Nigerian Agriculture and Rural life. CBN/NISER

[9]. Central Bank of Nigeria, Lagos (2008). Perspectives of Economic policy Reforms in Nigeria. CBN.

[10]. Chete, L. N. (2001). The Nigerian Banking Crisis: What Role Did the Macroeconomy Play? Savings and Development, 25 , No. 1.

[11]. Claasens, S. and Klingebiel, D. (2001). Competition and Scope of Activities in Financial Services. Working Paper, World Bank.

[12]. Dele, B. E. (2007). Banking Sector Reforms and the Nigerian Economy: Performance, Pitfalls and Future Policy. MPRA Paper No. 3804.

[13]. Ekpenyong, D. B. (2010). Finance and Economic Growth and Development in Africa. Book Chapter. Forthcoming.

[14]. Fry, M. J. (1997). In Favour of Financial Liberalism. The Economic Journal, 107: 754 - 770.

[15]. Gupta, K. L. (1984). Finance and Economic Growth in Developing Countries. London: Croom Helm.

[16]. Guryay, E., Safakhi, O. V. and Tuzel, B. (2007). Financial Development and Economic Growth: Evidence from Northern Cuprices. International Research Journal of Finance, 8: 2 - 8.

[17]. Haslag, J. H and Koo, J. (1999). Financial Repression, Financial Development and Economic Growth. Working Paper No. 9902, Federal Reserve Bank of Dallas.

[18]. Honohan, P. (2000). How Interest Rates Changed under Financial Liberalization: A Cross -Country Review. Working paper No. 2313, World Bank.

[19]. Hornby, A. S. (2001). Oxford Advanced Learner's Dictionary. $6^{\text {th }}$ Ed., Oxford: University Press.

[20]. Ivine, S. (2008). Political Reform -Key to Social reform. The Octagon, October 13, pp. 3 - 12.

[21]. Kling, R. G. and Levine, R. (1993). Finance and Growth: Schumpeter Might be Right. Quarterly Journal of Economics, 108: 717 737.

[22]. Lane, P., and Milesi-Ferretti, G.M. (2006). The External Wealth of Nations Mark II: Revised and Extended Estimates of Foreign Assets and Liabilities, 1970-2004. Working Paper No. 06/69, Washington: International Monetary Fund.

[23]. Levine, R. (1997). Financial Development and Economic Growth: Views and Agenda. Journal of Economics Literature, 35 (2): $688-726$.

[24]. Levine, R. (1998). The Legal Environment, Banks and Long run Economic Growth. Journal of Money, Credit and Banking, 30: $596-613$.

[25]. Levine, R. and Zervos, J. (1998). Stock Markets, Banks and Economic Growth. American Economics Review, 88: 537 - 58.

[26]. Levine, R., Norman, L. and Beck, T. (2000). Financial Intermediation and Growth: Causality and Causes. Journal of Monetary Economics, 46 (1): 31 - 77.

[27]. Morrisey, E. (2008). The Argument for Intervention. Available at www.intgovbk.org, 05/05/09

[28]. Ncube, Mthuli (2007). Financial Services and Economic Development in Africa. Journal of African Economics, Vol. 16 AERC Supplement 1: 13 - 57 .

[29]. Ndiyo, N. A. (2005). Fundamentals of Research in Behavioural Sciences and Humanities. Calabar: Wusen Publishers.

[30]. Nissanke, M. (2007). Discussion on the Financial Sector Reform and the Economy Analytical and Empirical Evidence of the Linkages. Paper at FSS 2020, Abuja.

[31]. Ogunleye, R. W. (2005). Monetary Policy Influences on Banks' Profitability: Evidence from single Equation Approach. BDIC Quarterly, 15 (14): 20.

[32]. Okagbue, S. N. and Aliko, T. B. (2004). Banking sector Reforms in Nigeria. Journal of Finance and Economics, 2 (2): 2 - 10.

[33]. Owoye, O. (1997). Money and Economic Activity in Developing Countries: Evidence based on Cointegration and Causality Tests. American Economist, 41 (1): 70 - 82.

[34]. Patrick, H. (1966). Financial Development and Economic Growth in Underdeveloped Countries. Economic Development and Cultural Change, 14: 174 - 189.

[35]. Rajan, R. G. and Zingales, L. (1996). Financial Dependence and Growth. University of Chicago Mimeo, May 15.

[36]. Rajan, R. G. and Zingales, L. (1998). Financial Dependence and Growth. American Economic Review, $88: 559$ - 586.

[37]. Rajan, R. G. and Zingales, L. (2003). The Great Reversals: The Political of Financial Development in the 20 ${ }^{\text {th }}$ Century. Journal of Monetary Economics, 69:50 - 55.

[38]. Ray, A. (2007). Trade and Pricing Policies in World Agriculture. Finance and Development, 23 (3): 2 - 5

[39]. Shan, J. Z., Sun, F. and Morris, A. (2001). Financial Development and Economic Growth. Review of International Economics, 9 (3): $443-454$

[40]. Sirri, E. R. and Tufano, P. (1995). The Economies of Pooling. In: Dwight, B. C. (Ed.), Global financial system: A functional Perspective. Oxford: Harvard Business School Press, pp. $81-128$

[41]. Soludo, C. C. (2004). Consolidating the Nigerian Banking Industry to Meet the Development Challenges of the $21^{\text {st }}$ Century. An Address Delivered to the special Meeting of the Bankers' Committee, Held on July 6, 2006 at the CBN Headquarter, Abuja.

[42]. Soludo, C. C. (2007). Financial System Strategy 2020: Nigeria's Financial System Strategy 2020 Plan our Dream. Paper Presented at the FSS 2020 International Conference, Abuja.

[43]. Theodore, B. (2007). Structure of Social Reform. The Octagon (October), 13 (1): 1 - 5

[44]. Tobbin, J. (1965). Money and Economic Growth. Econometrica, (October), 30 (4): $671-684$

[45]. Ubom, U. (2008). Banking Reforms Policies in Nigeria: The strategic option. Unpublished Research Paper.

[46]. Umoh, P. N. (1995). Assessment of Attempts at Monetary and Financial System Reviews in Nigeria. NDIC Quarterly, 5 (3): 27 43.

[47]. Wilson, I. (2005). Adjustment in Africa: Reforms Results and Ahead. World Bank Policy Research, New York: Oxford University Press.

[48]. Wyplosz, C. (2007). The Foreign Exchange Reserves Build-up: Business as Usual? Working Paper, Geneva: Graduate Institute of International Studies. 